\title{
The "Awful" Inevitable Fact for the Typical Policeman: Time to Retire!
}

\author{
Sinan Çaya* \\ Boğaziçi University, Turkey
}

Submission: January 10, 2017; Published: February 03, 2017

*Corresponding author: Sinan Çaya, Boğaziçi University, Institute of Environmental Sciences, Istanbul, Turkey, Email: sinan.caya@gmail.com

\begin{abstract}
In spite of the hardships and deprivations it involves, the law-enforcer's profession is indeed a beloved occupation providing the individual with authority, feelings of being privileged, honor and accordingly an immense work satisfaction. It is just on those grounds that it is extremely difficult to part with the job, as a retiree. Even the times when retirement is approaching represent a delicate, critical and emotion-rich stage. Therefore; before the precise retirement time does strike; on one hand, a policeman should prepare oneself psychologically for this phase of his life in a proper manner and on the other hand, the organization may in that respect be helpful and orienting, if possible through convenient courses, in establishing a smooth and problem-free transition onto civilian life.
\end{abstract}

Keywords: Policeman; Job; Profession; Retiree, Retirement; Authority; Privilege

\section{Introduction}

Retirement is actually a stage of life worth of living. Achieving retirement represents peace and fulfillment, in a sense. People without a pension lead tragic lives and they admire the regular retirement pays of others. Moreover; retirement involves attainment of a certain point in one's life span, related to age, and accordingly, it should be associated with happiness. Nevertheless; what one loses through retirement is also an undeniable fact of life. For certain professions those losses overweigh the gains in a more conspicuous manner. Police job probably comes at the top of such professions. On various grounds; the retirement of a cop is substantially more difficult to endure. Even the approach of the determined date embitters life considerably, in accordance with the Turkish proverb: The mentioning of certain situations is even worse than their real happenings.

\section{Parting with the uniform}

The main trauma of the policeman is saying farewell to the formal dress (In this particular sense, some other professionals like firemen, customs officials, sailors and the military people share with cops the bitter experience of leaving their uniforms, upon retirement). The uniform, above all, used to render his social status visible in the eyes of the public, a very special situation. (Indeed, in many countries, it a crime for the layman to wear a police uniform; except in certain circumstances like on the stage, for an actor). Many uniformed professionals universally and invariably identify themselves with their attire.
As sociologist Cooley defines it; the looking-glass self makes it a necessity, anyhow: Namely, the others see such professionals as representatives of their official organizations instead of sheer individuals. The members of the profession, accordingly, come to unify with their outer appearances, merely as a natural consequence of the mentioned awareness.

Any cop can talk about a similar experience: When introduced to the guests at a party, a fall in rhythm of amusement is registered. This is because they regard him merely as a representative of the moral authority. Or, an angry civilian "enslaving" him in a social environment starts a litany about his resentment towards law-enforcers, the abuse of power or the silly local car parking rules; in an ecstatic voice [1]. In the novel by Wambaugh [2], The Blue Knight, it is mainly the policeretirement issue which is taken up by the author. The first as well as the last pages deal with the task of polishing the breastinsignia of the uniform. Old hardware dealer Rollo is the best man in town for this transaction and he always performs this act, which is almost a ritual, with the utmost care. He also sells metallic plates, badges, facings, decorations. As a matter of fact; all official pompous emblems are actually coats of arms which the outsiders load with exaggerated importance in their minds merely out of admiration; in accordance with the Turkish proverb: The hens of the neighboring farmyard appear as if they were geese, instead. 
Baker [1] emphasizes this point very well: Cops raise their hands and get sworn into the profession upon graduation. Each is bestowed with a shiny badge. However, this metallic piece proves to be a lot less heavy in weight than expected initially. Moreover, each graduate attaches a gun to his belt. This weapon keeps getting bulkier along the course of time just as his own fate throughout his career. The mayor, the chief of police and acquaintances express their congratulations. Each graduate is a cop, as of today! Essentially retirement is a problem for anybody whose personality identifies with his professional status and income [3]. Losing the privileged police identification card (When I was a police-chemist at the Central Criminalistics Laboratory of the Security General Directorship of Turkey, in Ankara, a middle-aged cop, an expert in packaging of hard evidence material for transport, was sometimes chitchatting about his prospecting plans regarding his approaching retirement. On such occasions, he was mumbling bits of sentences about keeping his card instead of meekly presenting it to the administration. The eavesdroppers were only grinning wisely. After all; even the cards' formats are changed from time to time and his dream was nothing but a resort to a certain psychological defense mechanism, namely regression. In other words, it was just displaying a puerile demeanor. As for me; my resignation at a young age due to family affairs would spare me such a later crisis at middle age, fortunately) and the issued gun reinforces the trauma of losing the fancy uniform (Figure 1).

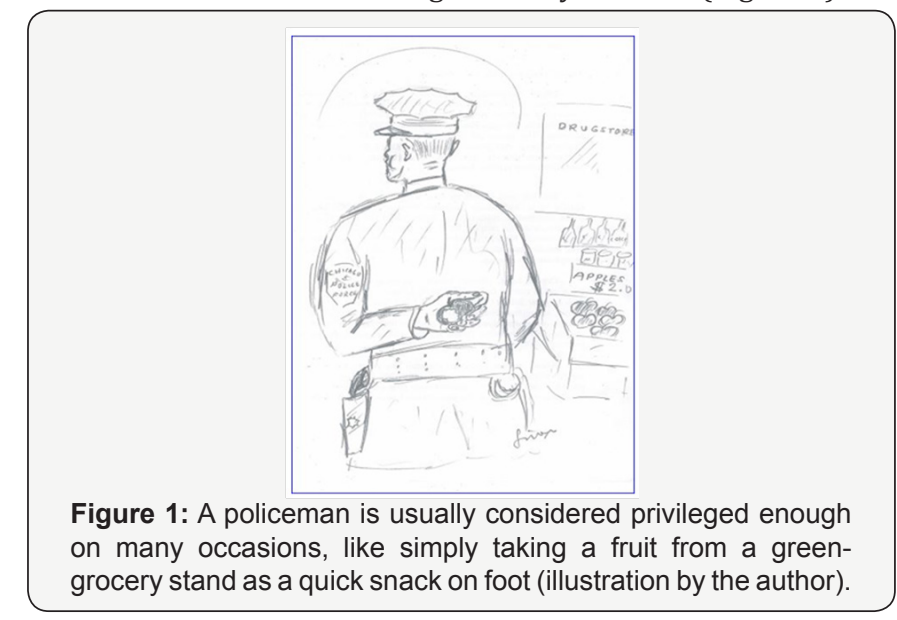

For plain clothes cops, this card constitutes a much more precious possession, naturally. As for giving back the issued gun; we can say that this transaction represents another material and simultaneously symbolic loss. True, in some places like certain American states, obtaining a small firearm is not a big deal, even for the ordinary citizen. But in many countries, obtaining or carrying a small weapon involves complicated legal procedures and a number of restrictions along with it. Indeed, the movie titled "The Missing Gun" (2002) vividly depicts what agitation and excitement emerges when, in a small town in Red China, a cop discovers that his gun is stolen. In another work by Wambaugh-whose title escaped my memory-a newly-retired detective is mentioning about a colleague soon-to-gain his pension of invalidity, in a manner which reflects professional jealousy over the man's very last moments on the job. He says that this colleague has not yet turned in his badge and he can still flash it, if necessary! An untimely retirement through disability is obviously more difficult to cope with, in comparison to a farewell to the job due to the prescribed age. As Kaplan, Sadock \& Grebb put it [3] adapting to retirement is especially hard for persons who are unprepared for the day.

\section{The loss of the right to intervene}

A cop has the right (as well as the obligation) by law to intervene any suspect-arousing situation. (In Turkish Criminal Law, in the case of witnessing, in person, the commitment of a felony/heavy crime, any citizen automatically is granted the right to intervene). For a policeman, use of this right gets to be a mechanical habitude (Years ago, I had a friendly talk with a cop while waiting for a late train. He was stationed at a west Anatolian city. On one occasion, he said that he was very much concerned about good manners and principles of hygiene. (No doubt a busy body in the opinion of many) He pointed out that he would reprimand any cook or waiter working in a stained white smock frock or any grocer with unclipped fingernails. He grounded his concern on the fact that a cop was a general constabulary, unlike and well above the other entire specific ones (prison guards, municipality inspectors, forest protection functionaries, rural gendarmerie, coastal guard etc) with time. When the person is deprived of this long-seasoned right, a feeling of futility and emptiness takes him over. The loss of the right of intervention is a more serious blow for the former detective. Upon the sight of an officially dressed cop, the parties of a simple fight or misdemeanor pull themselves together. As a matter of fact, any "fishy" individual takes care not to confront a policeman, to begin with. Navigation in walk included, he employs various techniques to avoid the law-enforcers. It is usually a detective who introduces himself as a surprise and investigates a suspicious happening, with authority (Figure 2).

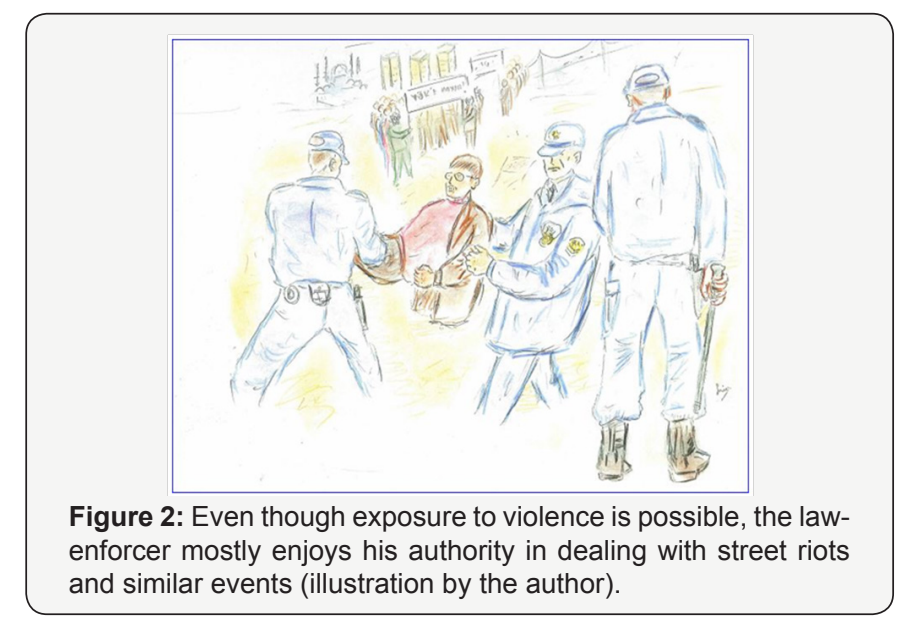

\section{The perceived loss of prestige}

The retired policeman will not experience the former respectful attitudes directed towards his person. A famous 
anonymous anecdote of witty Nasreddin Hodja, Ottoman Times' best-known trickster, reflects the idea in a beautifully striking manner: Hodja was invited to a dinner reception. He put on his old robe and went. When noticed that nobody paid him any attention, he rushed back home, put on his new robe and fur coat, and returned to the reception. This time, they greeted him at the door, escorted him to the table and offered him the most delicious dishes. Each time they placed a plateful of food in front him, he dipped the collar of his fur coat into the food and said,

-"Eat, my fur coat, eat!"

Everybody was surprised. So, they asked,

-"What are you doing, Hodja?"

-"Since all this attention and generosity is extended to my fur coat, it might as well eat the food, too," he answered.

How can it be denied that in society, display of respect is sometimes a mere lip service due to the power of the involved subject, rather than an internalized attitude? Once the power is gone, there is no place left for hypocrisy and false flattery. One great shock of retirement is to face this bitter lesson, which in turn jeopardizes the self-esteem (The reciprocal socialization process is also true: If a functionary taken lightly by fellow employees ever gets promoted to a higher level by chance, he takes on behavioral patterns appropriate for this new role. He automatically begins to care for his attire, his speech and manners. My departed mother was a school teacher. As a pragmatic remedy for the class discipline, she used to appoint the toughest male student as the so-called class chief. Bestowed with responsibility, this boy would adapt good manners and appropriate behavior and moreover, he would impose them on the other students) tremendously. Man indeed is a social being and his perception of the outer reality occurs via a cognitive chain, tinted with his subjective interpretation. While retirement represents relief from work burden and committing oneself to hobbies, for some, it is a time of stress due to economic problems or detriment to one's self-image [3]. The reason why some old retirees rest against their memories of former bright achievements, just like leaning on a walking stick, follows from such feelings of deficiency, as a compensation/defense mechanism.

\section{Loss of comrades}

Another shock is imparted by the loss of workplace comrades. It is a known fact that all over the world, a differently cohesive solidarity (When I was an undergraduate, I once had a summer job at the Turkey-Bulgaria frontier line. A passport policeman I got acquainted with was displaying a sorrow, crying face one morning. He said that he had just received some bad news from the wireless set. A colleague got stabbed by a young Hippie-tourist in Istanbul. The event got on his nerves and I admired this magnificent display of solidarity) among policeman is famous, just like in other perilous jobs. Moreover, the social world of a cop usually consists of fellow cops and their families.
A police officer would explain this fact by the extraordinary duty schedule. Changing patrol hours and unexpected overtime activities would isolate them from folks subjected to regular work hours.

If one does not show up at pre-determined appointment, he gets excluded [1]. But the same author [1] admits racism, discrimination and exclusion and harassment of female members, as a peculiar paradox. He adds that the same wellknown comradeship has another very delicate aspect regarding personal relations. If one officer is accused of something or undergoes an investigation, he is immediately ostracized from the brotherhood. Being associated with the suspected member is a potential danger for each one of them.

\section{Problems shared with all retirees}

In addition to the difficulties pertaining to cops alone; there is also the common problems of all retired people, due to the ending of a given duty or occupation. The usual remedy is orienting oneself to certain pastime activities. The awareness of the presence of similar people around also provides a psychological relief, in accordance with the Turkish proverb: a misfortune shared with others resembles a festivity of some sort, in a certain sense. Retirement necessitates developing new outlooks and interests besides adaptation into a different life style. For a male, this change in status resembles the menopause of the female. The new situation involves a return of dependency and therefore the revival of formerly repressed child fears and obsessions regarding lack of possible solutions [4]. Late Professor Metin (1927-2008), author of works about Turkish shadow plays (Schattenspiel) once related a family memory. They went for a visit to another house. The host husband was a retired Air Force general, a morose man sitting in a niche and getting lost in contemplation. The author felt sorry for him but also took a lesson from his situation. He grasped how dangerous it would be to stick to a certain lost occupation insistently with a fixed idea. This one-dimensional attitude must be avoided, he concluded.

When one comes to think of it; as Baker [1] puts it; the duty of the cop is far from exciting Hollywood illusions, anyhow. The detective knows that his world is much less glorified than what the public opinion assumes it to be. In this specific respect, retirement should not be the loss of such a great asset, anyway. In America, the average policeman, during a work time of two decades does not shoot a gun even once! Some shoot guns in polygons. But the weapon is always there, hanging from the hip (While I was working for the Police Lab in Ankara, one of the colleagues, another chemist, Vehbi, once asked a cop in charge of a section:

- "Suppose you won the big National Lottery prize. Would you quit your job?"

- "Who knows?" said the other. "Perhaps I would".

- "No, you would not! You would not deliberately deprive 
yourself from that issued gun touching your buttocks!" replied the forensic expert. Now, the other only kept his silence in face of this strong assertion) or tied to the ankle in a Velcro-fastened sheath.

At nights, it is on a nearby table or under the pillow. It is an ego-booster [1]. It would be interesting to note that a similar idea appears as a sub-theme in the movie Jarhead, 2005, about the first Gulf War. Swofford is an enthusiastic marine. He and his buddy Troy get hot training for dessert conditions. They get bored and frustrated. When the actual fight ensues, the two buddies, having lost their way on the dessert, get exposed to friendly fire from their own airplanes. When the two finally join their unit at night, they witness a crazy party. The war had ended and fellow soldiers are jovial! Swofford tells Troy that he hasn't given a single shot with his rifle. Troy tells him to go ahead and do it right now. He does so. Other soldiers join him and shoot into the air, ceremoniously.

\section{Impressions from a Novel}

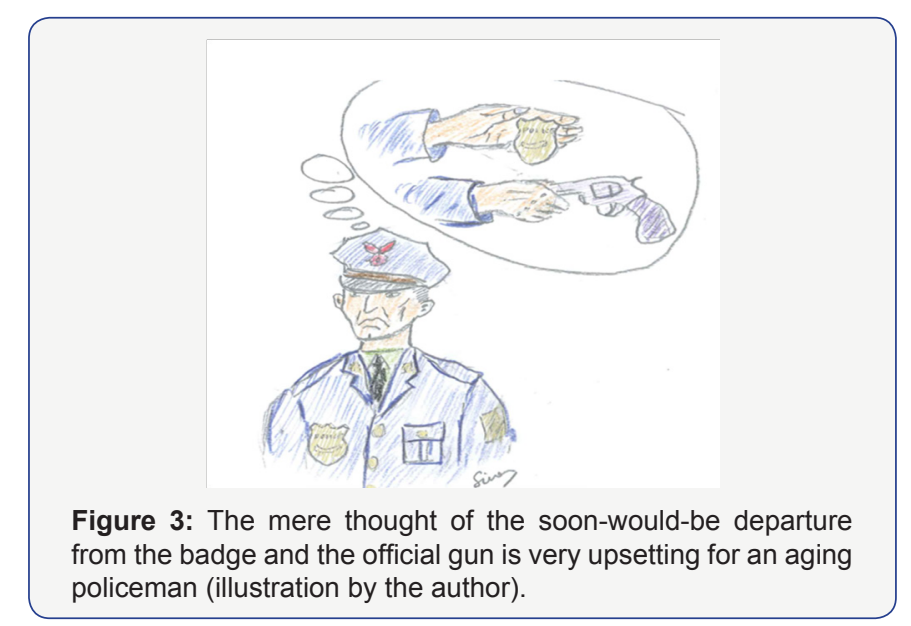

Wambaugh, that magnificent author of police themes, deals with many aspects of the job in his various works; but in The Blue Night, it is basically the matter of retirement which is under scrutiny, with the accompanying thoughts and feelings (Figure 3). Time is 1970s. The place is Los Angeles. The protagonist is a big half-a-century-old patrol policeman, Bumper Morgan. He narrates the unfolding events, himself. His new girlfriend is Cassie, a widow French teacher. She is about to move to a school in San Francisco. Bumper himself has arranged a prospective private security job in the same city. They plan a soon-to-be wedding there. Only one friend is initiated into those intimate plans: Hispanic colleague Cruz. Unlike his friend, Cruz is of small stature. He is a happy family man with children. The man has made it to the rank of sergeant despite his defected knowledge of English. He is the one who advises Bumper to retire and settle down, the sooner the better. Bumper would, in this manner, finally free himself from the merciless street life, the importunate figurative puta (prostitute), in the wording of Cruz.

In fact, this coming Friday, Bumper will get his yearly vacation and settle the retirement as a surprise-attack to his department via remote correspondence. All peddlers and shopkeepers and riffraff closely know this hulky, muscular middle-aged patrol cop. His appetite is famous (or maybe rather infamous). No owner of an eatery ever gets money from him. He visits a certain place seldom, not abusing this privilege regularly. Either. Besides, he always leaves tips for the waiters. Bumper has some street informers whom he also pays small sums from his own pocket, in exchange for valuable first-hand information. He occasionally suffers from indigestion and takes tablets. He is a long divorcee. His profession embodies his family-life, as well. His ego is a bit too swollen. Nowadays he is driving his blackand-white patrol car alone. In the past, he too had partners. The young ones were, he claims, bum-pe-ri-zed by himself. (Here we encounter the concept of initiation or rites of passage (rites de passage / Übergangsriten), coined by Arnold van Gennep: In primitive cultures those rituals represent passing from one phase onto another. Through a physical or moral test, a child gains a new status, that of a warrior [5]. While such ceremonies are less conspicuous in industrial societies, they still survive like in the case of wedding rituals [6]).

Recently many things had gone wrong with his job. Those things have upset the tired man. In his last days in his profession Bumper is melancholic and his analysis of events is rather philosophical. He visits Cruz and his Hispanic family for a dinner. He indulges in the peppered dishes cooked by Cruz' wife. The two men chit-chat after the meal over a glass of Mexican liquor. The small man oozes in his chair and his friend carries him to his bedroom in his strong arms and leaves the house with goodbyes. The next day after work he goes to a Lebanese-Arabic eatery. He had fraternized with the owners a few years ago, on an eventful day. The belly-dancer is a half-breed Arabic girl. She asks for a favor from the drunken cop. Could he influence the parole officer to turn a blind eye to her short abortion-travel in a different state? The reader learns the details of the man's first failed marriage and his dead son from bits of drunkard-speech, at this very moment. On the morning of the next work-day, he revisits a dairy in the neighborhood. To cure his hangover from last night, Bumper eats a plateful of yoghurt. On top of it, he drinks some butter milk.

The salesgirl first commits the error of giving him a half-liter container. She makes up for her mistake by issuing a second one afterwards, adding up to a liter together. Bumper thinks that this offer of free yoghurt and butter milk would be the very last one. Meanwhile Cruz enters a shop to get a farewell gift for Bumper. A small gangster on the verge of armed robbery, within the shop, gets excited upon the sight of the uniform and fires his arm. Cruz dies on the spot. Bumper gets informed and comes over at once. He takes the Catholic rosary from the dead man's pocket, giving an explanation to the detective in charge. That rosary was Cruz' talisman. It was offered to the man in his boyhood by his English teacher for making progress in his class. Bumper regards it as a private issue not to be displayed openly. Informing the family is also incumbent upon Bumper now! Confused under the impact 
of the sudden developments, Bumper calls Cassie and disowns all future plans about retirement, wedding and moving elsewhere. Cassie starts crying over the phone but he remains untouched. On the very last scene, we see him in the formerly-mentioned hardware shop, getting his breast-insignia re-polished.

\section{Conclusion}

Retirement is an important turning point in the lives of many and it may bring in a lot of goodness, too. For the policeman, however, this turning point in life is much more difficult and stressful. Certain material losses but more importantly nontangible losses in prestige, honor and prerogatives are definitely encountered.

\section{References}

1. Mark Baker (1985) Cops: Their Lives in Their Own Words. Simon \& Schuster, USA.

2. Joseph Wambaugh (1983) Der Müde Bulle [The Blue Knight]. Wilhelm Heyne Verlag, Germany.

3. Harold I Kaplan, Benjamin J Sadock, Jack A Grebb (1994) Synopsis of Psychiatry, Behavioral Sciences, Clinical Psychiatry $\left(7^{\text {th }}\right.$ edn). Williams \& Wilkins, UK.

4. Solomon, Philip, Patch, Vernon D (1974) Handbook of Psychiatry. Los Altos: Lange Medical Publications, USA.

5. Norbert Sillamy (1967) Dictionnaire de la psychologie. librairie Larousse, France.

6. Abercombrie Nicholas, Hill Stephen, Turner Bryan S (1994) Dictionary of Sociology ( $3^{\text {rd }}$ edn). Penguin Books, USA.

Your next submission with Juniper Publishers will reach you the below assets

- Quality Editorial service

- Swift Peer Review

- Reprints availability

- E-prints Service

- Manuscript Podcast for convenient understanding

- Global attainment for your research

- Manuscript accessibility in different formats ( Pdf, E-pub, Full Text, Audio)

- Unceasing customer service

Track the below URL for one-step submission https://juniperpublishers.com/online-submission.php 